\title{
Racial Conflicts in Tony Morrison's The Bluest Eye: A Literary Analysis
} Sujana Suvin*

Lecturer, Department of English, Gono Bishwabidyalay, Savar, Dhaka, Bangladesh

DOI: $10.36347 /$ sjahss.2020.v08i11.003

| Received: 29.10.2020 | Accepted: 10.11.2020 | Published: 30.11 .2020

*Corresponding author: Sujana Suvin

Abstract

Racism is a belief in the superiority of one race to another which results in discrimination and prejudice towards people based on their race or ethnicity. The life of African-American colored people has been affected by racism. For this purpose, the paper tries to focus on a system where chauvinism, malevolence, and domestically sexual harassments against Pecola Breedlove whose only target is to achieve beauty, which means happiness and survival. The novel portrays the effect of discrimination on a budding teenager's sexual being that put her in a gloomy and scary atmosphere from where the character was unable to leap out. The novel shows the prejudices that create a crater in the black man's psyche and his unexposed aggression on the white world led to his psychological repression. Toni Morrison's The Bluest Eye presents black cultural heritage and solicits the African-American to be proud of female black identity. Thus, this paper would like to examine the nature of the black people's struggle for their race and endurance in a multicultural postcolonial white America.

Keywords: Racism, Pecola Breedlove, Morrison, The Bluest Eye, and Pauline.

Copyright $\left({ }_{0} 2020\right.$ The Author(s): This is an open-access article distributed under the terms of the Creative Commons Attribution 4.0 International License (CC BY-NC 4.0) which permits unrestricted use, distribution, and reproduction in any medium for non-commercial use provided the original author and source are credited.

\section{INTRODUCTION}

Toni Morrison's first novel The Bluest Eye 1970 is an ironic commentary on the female body discourse, questioning one of the criteria of the AngloAmerican concept of physical beauty. Through several layers of voices and different narrative techniques, Morrison tells us the shocking story of a black little girl named Pecola Breedlove, who descends into madness after being emotionally and physically abused on several occasions by the entire community around her and by her family. Through the stories of Pecola and the people who surround her, the novel brings to discuss matters such as gender, race, and identity and raises questions on racial self-loathing, the menace of white beauty standards, and the loss of one's self. This study aims to analyze how concepts of identity to race is manifested in the novel, how it can be read as a claim for racial pride, and what Morrison's suggestion for a healthy, healed identity is [1].

The dilemma of the African-American woman is based on racial and sexist oppression that marginalizes her where she is confined in a pitiful state of nothingness. This double oppression is presented in Morrison's novel The Bluest Eye. This article would like to investigate how African -American women have tragically fallen under the destructive spell of sexism and racism and, marginality [2]. In this novel, the novelist has wanted to present the real picture of racial conflicts through the portrayal of women characters, including Pecola Breedlove.

\section{LITERATURE REVIEW}

African-American women writers give passion and a desire for survival. It is literature that reconstitutes human value and gives back to black women that was stolen, denied, ignored, and deemed. Black women writers align their work closely with the realities of African-American women's lives by exposing the barriers thrown up by patriarchy and racism to self-knowledge, self-love, and individual wholeness. They investigate the effects such barriers impose upon the development of characters, like Pocola in The Bluest Eye by Toni Morrison [3].

In an article "Black Feminism: What Women of Color Went Through in Toni Morrison's Selected Novels" Rahmani writes that Toni Morrison sheds light on the unspoken truth of the inhumanity of humans to each other. To understand Morrison's novels, it is important to have enough knowledge about American history and its culture. The novel The Bluest Eye was written during the 1960s when racism was common in American society and according to the values and beauty standards of the society beauty meant to be 
white and to have blond hair or blue eyes. In this novel, the central character Pecola Breedlove hates her appearance and she thinks that others hate her because of her blackness. Unfortunately, her mother Pauline is the source of the same belief that has been transferred to her daughter Pocola.

The black culture presented by a black writer is one of the strengths in The Bluest Eye as Morrison looks at the black culture as the oppressor and the oppressed as well: the oppressor of black women and the oppressed by the racism of a white-dominated society [4]. Morison's The Bluest Eye presents three important issues or sides of a triangle: sexism, racism, and marginality. This triangle relationship deeply portrays the dilemma of black women and exposes their intricate situation. Sexism includes patriarchal oppression represents in black males who, under the stereotype of weakness and emasculation, practice the most sexist oppression against their fellow women. How classism marginalizes the poor, make them collect self-contempt by heaps, and degrade them to an animal plane is evident in The Bluest Eye. Morrison's characters act, interact, suffer, alleviate, or dominate in tune with their economic status. It is the economic status of Pauline Breedlove and her limited options in life that prompts her to slap her child to please her white master's child. It is their financial status that pushed the Breedlove family to outdoors. It is not Pecola's ugliness but her poverty that makes her accept meekly the disgrace from a petty shopkeeper to that of Geraldine, the rich black woman who treats her like an untouchable animal. The insecurity of the female gender in this novel and its degrading effects on the tender mind and resultant tragic insanity is more economic oriented rather than societal conditioning [5].

In the thesis, Identity, Race, and Gender in Toni Morrison's The Bluest Eye, Gomes points out that Morrison's wariness towards the "Black is Beautiful." The existence of something beautiful will require the existence of something ugly excluding and harming someone. Both Morrison and Cheng seem to think that the fact that whiteness is considered the most important or only kind of beauty is not the only problem, but also that the whole importance attached to this particular value is misguided. There are signs in the novel that point to Morrison's concerns towards the "Black is Beautiful" slogan, and not all of them are subtle [6]. The explicit one is when the narrator refers to the notion of physical beauty that Pauline learns at the picture, which represents the "destructive ideas in the history of human thought" -the other being romantic love" [7].

In the essay, "Race and Gender in Toni Morrison's The Bluest Eye," Rajabi says that Morrison argues that race which she has presented in quotation marks has always been an integral part of American culture and literature as she phrases it, for both black and white American writers, in a racialized society, there is no escape from racially inflected language. She vehemently disagrees with the consensus among literary scholars who claim that race was not meaningful to the construction of American identity. What has made America distinctively American was the real Africanism, which functions as the vehicle by which the American self knows itself as not enslaved, but free; not repulsive, but desirable; not helpless, but licensed and powerful; not history-less but historical; not damned, but innocent; not blind accident of evolution, but a progressive fulfillment of destiny. Morrison thinks that the concept of the blacks' inferiority not only adversely affected black people, but also reciprocally affected white people and the way they imagine their roles in society [8].

Seraman and Selvakkumar argues that The Bluest Eye portrays in poignant terms the tragic condition of the blacks in racist America. It examines how the ideologies perpetuated by the dominant groups and adopted by the marginal groups influence the identity of black women. Bombarded by the image of white beauty, Morrison's characters lose themselves to self-hatred and their only aim in life is to be white. They try to erase their heritage, and eventually, like Pecola Breedlove, the protagonist, who yearns for blue eyes, has no recourse except madness [9].

Dar, Ahmad, Mir, and Ganaie expresses their views that the racial discrimination in post-colonial literature has fostered the main issue of many writers. African-American writers have not only represented themselves, but also their race and culture. They try to establish their Afro- American identity through their magnificent writing. Among them Toni Morrison, the Afro-American novelist raises this issue in her novels, including The Bluest Eye on behalf of racial victims. In America, racism is a reality. In the postmodern context, the voices against racial discrimination get more focus and prominence. Toni Morrison has become the mouthpiece of the colored people. Her writings are tales of the colored people's oppression in a white-dominant patriarchal society. Morrison has realized very early in her life that racism has become the greatest enemy of the colored people. She has tried to justify that getting back the black identity is the only way to check the racial discrimination. She knows a problem specific to groups targeted by racism that Afro-Americans begin to believe about themselves and imagine that EuroAmericans are superior in beauty, morality, and intelligence. Morrison is very well-known for her AfroAmerican identity for upholding the complex life of the black slaves, other men, and women who are living in highly backward and neglected conditions in America. They are not only hated by the white men and women of America but they are also treated in a manner worse than animals. She is much more concerned with the life and improvement of the black community [10]. 


\section{Theoretical Framework on Racism}

Inferiority complex is linked to historical racist doctrine and racist social systems. Slavery, segregation, imperialism, apartheid, and Nazism all treated certain groups as inferior to other groups (mostly the dominant group, although sometimes other non-dominant racial groups) because of their biological nature [11]. Inferiority complex is expressed in various attitudes and behavior-disrespect, contempt, derision, derogation, demeaning. It can involve a developed set of beliefs about a biologically based hierarchy of races, but it need not do so. For one thing, an individual may be racist against only one racial group and have no views about others. An individual can be contemptuous toward another racial group without believing that its members are inferior. A white or black person, for example, may grow up in an environment in which Mexicans and Mexican-Americans are routinely treated and regarded with contempt [11].

On reflection, she may realize that she does not believe Mexicans to be inferior or otherwise worthy of contempt, yet her manifestations of contempt toward Mexicans will become racist [12].

Racism is the belief that groups of humans possess different behavioral traits corresponding to physical appearance and can be divided based on the superiority of one race over another [13]. It may mean prejudice, discrimination, or antagonism directed against other people because they are of a different race or ethnicity [14]. Modern variants of racism are often based on social perceptions of biological differences between the nations. These views can take the form of social actions, practices or beliefs, or political systems in which different races are ranked as inherently superior or inferior to each other, based on presumed shared inheritable traits, abilities, or qualities [15]. In terms of the political system that supports the expression of prejudice or aversion in discriminatory practices or laws, racist ideology include associated social aspects, such as nativism, xenophobia, otherness, segregation, hierarchical ranking, and supremacism.

The concept of victim-system control in social theory is developed in a particularly interesting way by Ryan. In a cogent and often brilliant analysis, he documents several theories of social organization that seem to blame the relatively powerless victims of social injustice for creating their problems. He notes that the new ideology attributes defect and inadequacy to the malignant nature of poverty, injustice, slum life, and racial difficulties. The stigma that marks the victim is an acquired stigma, a stigma of social rather than genetic origin. But the stigma, the defect, the fatal difference-though derived in the past from environmental forces-is still located within the victim, inside his skin. It is a brilliant ideology for justifying a perverse form of social action designed to change, not society, as one might expect, but rather society's victim [16].

Banks suggests that sociogenic theories contribute a great deal to the reinforcement of racial and social class stereotypes by preparing educators to expect and accept inadequacy from classes of students [17].

Kenneth Clark puts the matter quite succinctly when he argues that "cultural and economic backgrounds of pupils do not constitute a barrier to the type of learning which can reasonably be expected of normal children in the elementary grades" [18]. Rather, he feels that schools' loss of faith in their students and their potency lets these background factors become a barrier. Other barriers that need to be explored include low levels of curriculum diversity and quality, minimal options for bilingualism or biculturalism, teacher incompetence, the professional culture of educators, styles and values of whites running urban and largely black schools, educational leadership as political control, and the social function of black school failure for white advantage.

Park argues that the main feature of such relations was a consciousness of racial differences: Race relations, as that term is defined in use in the United States, are the relations existing between peoples distinguished by the marks of racial descent, particularly when racial differences enter into the consciousness of the individuals and groups so distinguished, and determine in each case the individual's conception of himself and his status in the community [19].

Marable emphasizes the politics of racism on some factors, but he draws particular attention to the role of black intellectuals and radical white intellectuals who have stressed in their work the importance of politics in determining the social and economic position of blacks in American society [20]. He cites also the experience of the riots of the 1960s as an important source of research on political power and powerlessness with racism. Some other studies of the American situation highlight similar processes, albeit from divergent analytical perspectives [21].

There has been a tendency within the literature to use the terms of prejudice and racism interchangeably. Jones makes the case that racism is distinct from prejudice. While prejudice is usually regarded as an individual phenomenon, racism is a broader construct that links individual beliefs and practices to wider social and institutional norms and practices. The belief in a racial hierarchy between groups is a central defining characteristic adopted by many theorists to define racism. For example, Jones defines racism as a "belief in the superiority of one's race over another, and the behavioral enactments that 
maintain those superior and inferior positions" [22]. The belief that the differences between racial groups are biologically driven implies that such variability is fundamental and fixed. Racism practiced at a structural and cultural level, maintains and reproduces the power differentials between groups in the social system [23]. Racial practice has been referred to as institutional and cultural racism. Institutional racism refers to the institutional policies and practices that are put in place to protect and legitimate the advantages and power one group has over another. Institutional racism can be overt or covert, intentional or unintentional, but the consequences are that racist outcomes are achieved and reproduced. Racism focuses upon characteristics of minorities can be found in recent reports of the causes of urban riots. Some studies of urban violence have investigated aggressive black responses to injustice and have interpreted riots in terms of impulsive expressions of black frustration and anger [24].

\section{Racial Conflicts in The Bluest Eye}

Morrison's first novel The Bluest Eye 1970, is inspired by the climate of the revelation and evolving black consciousness of the sixties, a period characterized by an almost evangelical struggle for personal and racial identity. Morrison chooses as the basic theme and subject for her first major work [25]. The novel deals with the theme of the obsession of blacks with an American standard of beauty that seems both inescapable and destructive, as Morrison states: "The concept of physical beauty as virtue is one of the dumbest, most pernicious and destructive ideas of the western world" [7].

The Bluest Eye is a tragic tale about a young black girl's desire for the bluest eyes, for her, this symbol means to be beautiful and therefore, worthy in society. The pivotal idea in the novel is the domination of blacks by the existing American standards of beautyblue eyes, blond hair, and white skin. It deals honestly and sensitively with the people. It portrays in poignant terms the tragic condition of blacks in a racist America. The character of Pecola Breedlove, the protagonist of The Bluest Eye, is based on a real-life girl whom Morrison meets when she is eleven years old. She and the other little girl discuss whether or not there is a God. Morrison thinks so, but the little black girl disagreed. The reason is that the little girl wants blue eyes, this is a deep heartfelt wish that she has not been granted. Morrison recalls her reaction well. She prays for two years for her blue eyes.

Morrison's thoughts in The Bluest Eye are to challenge the western standards of beauty and demonstrate that the concept of beauty is socially interlinked. Her concentration is not on the aesthetic level as much as ethnic and racial levels. According to Morrison, the African's self-image is destroyed at an early age as a result of the ruling class, promoting its standard of beauty. Long straight hair preferably blond, keen nose, thin lips, and lights eyes, preferably blue. By analogy, the physical features of the European are accepted as the standards of beauty, and then the African must be ugly. This is the type of logic that the Breedlove family convinces themselves of their ugliness [26].

\section{Racism in Beauty}

Morrison's The Bluest Eye presents the lives of different families: Breedlove, Mac Teer, and Geraldine family. The story is set in Lorain Ohio, a segregated steel industry town, in the early 1940s during the great depression when many black people immigrated from southern to northern cities in search of jobs. The novel has presented the problem which faces those blacks focusing on the tragic story of Pecola Breedlove, a black girl, and her parents who live in Lorain and face physical and psychological oppression from the white and black communities.

Morrison visualizes the miserable life of Pecola's family, and how this life affects Pecola to quest blue eyes. Morrison describes the Breedlove family and how they are living in an apartment which contains only one room which is separated into two parts by blankets. The furniture inside the apartment is old like its owners. The Breedlove family members accept the fact they are ugly. Not only do the whites in Lorain look down on them, but they accept the superiority of whites and accept to be less than them and less than all the community members in Lorain. They lose their self-esteem and stay back yard to hide their ugliness. Pecola's quest to obtain blue eyes to change the bad views of the community against her family because of their ugliness. The important influence on Pecola is her mother Pauline, who has been closest to her. Even though Cholly Breedlove commits horrible atrocities against his daughter and drives her to the brink of insanity. Pauline is a black girl from Alabama. When she is a child, a rusty nail pierces her foot [27].

One day Pauline meets a boy named Cholly Samson. He is from a poor family. Cholly suffers from humiliation by his own family. He is four days old wrapped into two blankets and abandons in a junk-heap by the railroad by his mother. His aunt Jimmy takes care of him and raises him. Cholly has six years of schooling before he takes a job at the son's feed and Grain store as an errand boy. When Chollyis fourteen, aunt Jimmy dies. Chollyis fussed over at aunt Jimmy's funeral. on the day of aunt Jimmy's funeral, Cholly runs off with Darlene to make love in the woods. Pauline and Cholly fall in love with each other and decide to marry and to immigrate to the north to search for a better life and job changes. Pauline describes his coming. He comes, strutting out of a Kentucky, sun on the hottest day of the year. He becomes strong, he comes with yellow eyes. 
However, racism within the same race is a major theme in The Bluest Eye. African-American identities are shaped by different concerns such as ancestry, wealth, education, or the darkness of their skin. The Bluest Eye presents several different AfricanAmerican families that expose prejudice to their fellow African-Americans and display their special social status. Pecola suffers because she is black and ugly, she spends hours looking at herself in the mirror, trying to discover that the secret of her ugliness. The ugliness makes her ignored or despised by her family, teachers, and classmates also. She is the only one in her class who sits alone at a double desk. Her teachers never try to glance at her, only when everyone in the class is required to respond.

On the other hand, Maureen is a newcomer to the school; she is very popular because she has the lightest skin of the white people. All the teachers and the pupils treat her kindly not like Pecola. They all wish to speak with her, the blacks and white pupils resect her not like the ugly Pecola. The reason for this treatment is because Maureen is the whitest of the colored pupils and the fact, she has a lot of money. Maureen insults Pecola in the street after the school ends by mentioning bad names on her father to remind her of her ugliness and less status. Pecola does not answer Maureen but stands motionless thinking about how she is ugly and is rejected by all members of the community. Even Maureen who is from her race sees her as an ugly outsider person among the other schoolgirl [27].

\section{Communal Racism}

Pecola faces another humiliation but now from the Geraldine family and her son Junior, a young colored boy living near the school playground. Junior is brought up to feel superior to other African- American children by his mother. His mother does not like him to play with niggers. He sees Pecola crossing the playground and takes advantage of her. Junior invites Pecola to his house to see his Kittens, but she is doubtful to accept this invitation. She accepts to see his house; she is amazed by the interior of the house and considers herself very lucky to have got there. Being aware of his superiority Junior is capable of doing anything, so he throws his mother's beloved cat on Pecola's face to scare the girl. The cat claws her face and drops nimbly to the floor.

Thus, Morrison criticizes the white society and she shows how this little black girl is the victim of the climate around her. Morrison indicates how is influential society can be on an individual and how strongly its ideas and views are impressed upon that individual. The ideas and views that she speaks of pertain to beauty and what makes and individuals beautiful. The idea of beauty turns girls' life upside down and, in the end, leads her to madness. Thus, Morrison's goal is to describe the negative effects of society's views on an individual and how the individual's life changes forever. Pecola is a symbol of effect, a damaged self-image due to racism can have. She is subjected to racism both within her race and by the white society. Morrison investigates how the perpetuation of beauty myth affects individuals, particularly female adolescents, through the characters of Pauline and Pecola Breedlove. One comes to understand the devastating effects that company the failure to succeed in achieving white standards of beauty. Characters in the novel are all linked because they accept other's truth as their own, thereby causing distorted self-images [27].

\section{Familial Racism}

Pauline continues through her life to seek approval in other's eyes particularly in her position as a servant for whites. In fisher's house, she gets everything she wants and needs. In doing so, she rejects the needs of her family entirely. Not even her daughter calls her mother. Instead, she is forced to call her Mrs. Breedlove as a symbol of the unfamiliarity of the connection that should be filled with love while it is filled with hatred and rejection. She prefers not only Fisher's house, but also Fisher's little girl. One day, Claudia and Frieda follow Pecola to her mother's workplace. When Pecola accidentally smashes a fresh-baked berry cobbler onto the kitchen floor and splatters the white child's new pink dress, Pauline knocks Pecola to the floor and consoles the white child as if she were her own. She attacks her daughter and, in turn, she denies her world when she not only fails to acknowledge Pecola, but also comforts the white family's chills [28]

However, Pecola is obsoletely suffering, raised by parents who despise and neglect her, and a community which hates her. Pecola's presence in The Bluest Eye is her absence. Pecola's ugliness, defined visually by white standards, faces her into a position of invisibility and absence, which in turn becomes her only mode of presence. Pecola suffers from the harsh reality of isolation, no one loves or encourages her. Her family does not support her, her teacher abhors her, classmates ridicule her, and people in the town ignore her. Her isolation, self-blame, and negativity of her life, finally escalate when she is in the kitchen washing dishes and her extremely drunk father becomes overwhelmed with sexual desire and rapes his daughter violating a standard code of familial relations.

Pecola, however, unlike the laughing Pauline, remains stiff and silent. Cholly shifts to the second train of thought, a second stimulus to self-assertion because Pecola does not make Cholly angry and stays silent and quit, this allows him to assert himself as a man, without the look of anyone, especially the white men who snap him his self-esteem before. By doing this Cholly's oppressed psyche since his boyhood makes him commit this action. He fails and Pecola blocks any way of hope and success. 
In the novel, the white esthetic violates Pecola's mind and ultimately drives her insane. Pecola is raped twice first by the dominant culture's ideology of whiteness that denigrates blackness and destroys her identity and later by her father. Cholly is dismissed twice by his father. Cholly does not understand what it means to love or know how to be a father. He does not know how to show his love toward Pecola. Therefore, he believes it is easier to ignore them. After Pecola's pregnancy, she is asked to leave school since she may spoil the other students. All people in Lorain's community find it a suitable opportunity to dismiss Pecola and the Breedlove family members from their city. She is during this time begins to slip into her madness. Pecola turns to Soaphead church, Pecola suffers from the isolation, her mother leaves the house and lives with the Fisher. Cholly dies in his work, and Pecola runs away. She reaches into a state of hallucination and creates an imaginary friend to talk with and this reinforces her isolation from the community.

At the end of the novel, she is isolated from the town physically and emotionally. Adults look away when they see her and children who are not frightened laugh at her. A young girl's life ruins as a result of society's placing of beauty on such a high standard and making the standard and its importance are known to all. Claudia and Frieda do not care about adult's hate for Pecola and they pray for her baby to live to "counteract the universal love of white body dolls, Shirley Temple, and Maureen Peals" [7]. Claudia begins to describe Pecola's schizophrenic. Her baby is born and dies while she wanders in the city.

Morrison uses Lorain's land where Claudia plants her seeds as a metaphor for the United States and the Marigold seeds as a metaphor for Pecola [29]. Pecola is like the Marigold seed. She is not able to grow up in this land because Lorain's environment neglects and rejects her. Pecola thinks that obtaining the blue eyes of all will make her desirable and loved by everyone in the community but all her dreams dissolve. There is no place for her sane, ugly, nor crazy. She has never been given the opportunity in any place or time to see a positive thing in herself [27].

\section{CONCLUSION}

Toni Morrison's The Bluest Eye shows how in the framework of an internalized racism all its components affect each other to produce a set of prejudices in which male and female characters endure and resist simultaneously. This set of prejudices incorporates psychotic perversion where the subject endures and then attempts to resist by deleting the fragmented image of the self-projecting the hatred onto the object. On the other hand, in the case of perversion in the racial discourse, Morrison has presented how the suffering subjects desire to identify with the inconceivable, idealized whiteness. In such a framework of internalized racism, racial victims are either sadomasochistic or delusional in their effort to defy the capitalist machine of racial subjugation [30].

Morrison focuses on black cultural heritage and solicits the Afro-Americans to be proud of their black identity through the character of Pecola Breedlove. Morrison has presented the blacks to understand that black identity is not inferior to white in any way. She makes her point that physical appearance and culture may be different but that does not mean servitude of the entire race [31].

\section{REFERENCES}

1. Mahdi, Maher A. (2015). Triangle of Hatred: Sexism, Racism, and Alienation in Toni Morrison's The Bluest Eye. Canadian Social Science, vol. 11, no. 9.

2. Gomes, Rosana Ruas Machado. (2016). Identity, Race and Gender in Toni Morrison's The Bluest Eye. Universidade Federal Do Rio Grande Do Sul Instituto De Letras.

3. Rahmani, Ayda. (May 2015). Black Feminism: What Women of Color Went Through in Toni Morrison's Selected Novels. International Journal of Applied Linguistics \& English Literature, vol. 4, no. 3, pp. 62-63.

4. Mahdi, Maher A. (2015). Triangle of Hatred: Sexism, Racism and Alienation in Toni Morrison's The Bluest Eye. Canadian Social Science, vol. 11, no. 9, pp. 45-51.

5. Lakshmi, Bh. V. N. \& Zainab Abdulaziz Al Suhaibani. (2015). Dicing with Class, Race, and Gender: Toni Morrison's The Bluest Eye. International Journal of Humanities and Social Science Invention, volume 4, issue 1, pp.40-46.

6. Gomes, Rosana Ruas Machado. (2018). Identity, Race and Gender in Toni Morrison's The Bluest Eye. Universidade Federal Do Rio Grande Do Sul Instituto De Letras.

7. Morrison, Toni. (1970). The Bluest Eye. London: Vintage Books, 1999.

8. Rajabi, Fatemeh. (2016). Race and Gender in Toni Morrison's The Bluest Eye. An International Refereed e-Journal of Literary Explorations, vol. 4 , issue III.

9. Seraman, Dr. N. and T. Selvakkumar. (2013). Race, Class and Gender Bias as Reflected in Toni Morrison Novel's The Bluest Eye. Indian Journal of Applied Research, volume: 3, issue: 2.

10. Dar, Nisar Ahmad, GH. Mohd Mir, and Javaid Ahmad Ganaie. (2018). Racism: Toni Morrison's The Bluest Eye a Mouthpiece of Cloured People. AGU International Journal of Research in Social Sciences \& Humanities, vol. No. 6.

11. Blum, Lawrence. (2002). "I'm Not a Racist, But [...]" The Moral Quandary of Race. Ithaca and London: Cornell University Press.

12. Nakashima, Cynthia L. (1996). Voices from the Movement: Approaches to Multi-raciality. The 
Multiracial Experience: Racial Borders as the New Frontier, edited by Maria P. P. Root. California; Thousand Oaks.

13. Dennis, R.M. (2004). Racism. The Social Science Encyclopedia, edited by A. Kuper, J. Kuper. Volume 2. London; New York: Routledge.

14. Ghani, Navid (2008). Racism. Encyclopedia of Race, Ethnicity, and Society, edited by Richard T. Schaefer. SAGE, p.1113.

15. Newman, D. M. (2012). Sociology: exploring the architecture of everyday life (9th ed.). Los Angeles: Sage, p.405.

16. Ryan, W. (1971). Blaming the victim. New York: Pantheon, 1971.

17. Banks, J. (1972). Racial prejudice and the black self-concept, black self-concept, edited by J. Banks and J. Grambs. New York: McGraw-Hill.

18. Clark, K. (1965). Dark ghetto. New York: Harper \& Row.

19. Park, R. (1950). Race and Culture. New York: Free Press.

20. Marable, M. (1981). Race, Class, and Conflict. Sage Race Relations Abstracts, vol6, issue 4.

21. McAdam, D. (1982). Political Process and the Development of Black Insurgency: 193D-1970. Chicago: University of Chicago Press.

22. Jones, J.M. (1972). Prejudice and Racism. Reading, MA: Addison-Wesley.

23. Jones, J.M. (1998). The essential power of racism: Commentary and conclusion. Confronting Racism: The Problem and the Response, edited by J.L. Eberhardt and S.T. Fiske. Thousand Oaks, CA: Sage.
24. Gurr, T. (1968). Urban disorders: Perspectives from the comparative study of civil strife. Riots and rebellion: Civil violence in the urban community, edited by L. Massoti and D. Bowen. Beverly Hills: Sage.

25. Sumana, K. (1998). The Novels of Toni Morrison: A study in Race, Gender, and Class. New Delhi: Prestige Books.

26. Mbalia, Doreath. (2010). Toni Morrison's Developing Class Consciousness. N.P Associated University Press.

27. Kadhim, Mohanad Mohammed. (2016). Racism as Reflected in Toni Morrison's Novels. A Thesis in Fulfillment of the Requirements for the Degree of Ph.D. in English Literature, Sudan University of Science and Technology College of Graduate Studies.

28. Bring, Maria. (2008). Racism within AfricanAmerican Communities in Toni Morrison's The Bluest Eye and Paradise. London: Vintage.

29. Walter, Tracey. L. (2007). African American Literature and the Classicist Tradition: Black Women Writers from Wheatley to Morrison. New York: Palgrave Macmillan Press.

30. Dar, Nisar Ahmad, Mir, GH. Mohd, Ganaie, Javaid Ahmad. (2018). Racism: Toni Morrison's The Bluest Eye a Mouthpiece of Colored People. AGU International Journal of Research in Social Sciences \& Humanities, vol. 6.

31. Khan, Md. Reza Hassan and Md. Shafiqur Rahman. (2014). The Framework of Racism in Toni Morrison's The Bluest Eye: A Psychosocial Interpretation. Advances in Language and Literary Studies, vol. 5, no. 2. 